\title{
Twentieth-century astronomical heritage: the case of the Brazilian National Observatory
}

\author{
Christina Helena Barboza \\ Museum of Astronomy and Related Sciences \\ Rio de Janeiro, Brazil \\ email: christina@mast.br
}

\begin{abstract}
This paper aims at contributing to the UNESCO-IAU Astronomy and World Heritage Initiative's discussions by presenting the case study of a 20th-century observatory located in a South American country. In fact, the National Observatory of Brazil was created in the beginning of the 19th century, but its present facilities were inaugurated in 1921. Through this paper a brief description of the heritage associated with the Brazilian observatory is given, focused on its main historical instruments and the scientific and social roles it performed along its history. By way of conclusion, the paper suggests that the creation of the Museum of Astronomy and Related Sciences with its multidisciplinary team of academic specialists and technicians was decisive for the preservation of that expressive astronomical heritage.
\end{abstract}

Keywords. Heritage, history of astronomy, observatory

\section{Introduction}

The National Observatory $(\mathrm{ON})$ is the oldest observatory in Brazil still in activity (Granato 2009). It was founded in 1827, soon after the political independence of that country, with the aim of transmitting practical astronomy to the students of the military and naval academies. From the mid-19th century to the early 20th century it was installed in the ruins of a Jesuit church located in the center of Rio de Janeiro, former capital of Brazil. In 1921 it was transferred to its present location, on the top of the São Januário hill. Since 1985 the wooded area of approx. $44 \mathrm{~km}^{2}$ where it is located is shared with the Museum of Astronomy and Related Sciences (MAST), a research institution originally created with the main purpose of studying and safeguarding the Observatory's old buildings and obsolete instruments (Barboza 1994).

\section{Brief inventory of the tangible heritage at the ON-MAST site}

The ON collection of moveable instruments, now under the safeguard of MAST, comprises approx. two thousand objects, which pertain to a wide range of scientific disciplines, such as astronomy, geodesy, topography, meteorology, magnetism and electricity, among others. They are evidence not only of the multiple activities developed in the Observatory at the turn of the 20th century, but also of its central role in the State building then in course, since the institution organized many demarcation expeditions and lent its instruments to other governmental agencies.

The immoveable heritage of the $\mathrm{ON}$ is formed by eight instruments sheltered in pavilions spread throughout the campus:

1) a $21 \mathrm{~cm}$ Equatorial refractor by Gustav Heyde; 
2) a $32 \mathrm{~cm}$ Equatorial refractor by Cooke \& Sons;

3) a $14 \mathrm{~cm}$ Zenith telescope by Gustav Heyde;

4) a $46 \mathrm{~cm}$ Equatorial refractor by Cooke \& Sons (the only one not belonging to the MAST collection);

5) a $7 \mathrm{~cm}$ Meridian circle by Askania;

6) a $8 \mathrm{~cm}$ Meridian circle by Bamberg;

7) a $19 \mathrm{~cm}$ Meridian circle by Gautier; and

8) a $10 \mathrm{~cm}$ Photoheliograph by Zeiss.

The majority of these instruments were planed for the new area in São Januário hill, but two of them, the $32 \mathrm{~cm}$ Equatorial and the Gautier circle, are 19th-century instruments. The Gautier was even installed in the old building of the ON. This obsolete instrument and its pavilion, in particular, recently underwent a deep restoration process, performed by the MAST team of museologists and technicians.

\section{Cultural and symbolic dimensions of the Observatory activities}

Between the end of the 19th century and the first two decades of the 20th century the ON became one of the most important scientific institutions in Brazil. Firstly, because under the direction of Emmanuel Liais (1871-1881) and his successor, Luiz Cruls (1881-1908), the links with the Military Academy were broken and it was given a variety of other tasks. Some of them had practical purposes, such as providing visual time signals useful to the ships and to the urban economic life in general, or establishing a meteorological network throughout the country, in order to understand the tropics and fight old climatic prejudices that were seen as the main threat to immigration. Other initiatives fit more strictly in what was then called "pure" science, such as the engagement in the international efforts to observe the Venus transit of 1882, or in the French "Carte du Ciel" photographic project. Anyway, it is possible to argue that during the last years of the Empire the ON rivalled with Cordoba and Cape of Good Hope Observatories in the discovery and investigation of celestial objects within the Southern skies. The Great Comet of 1882 (1882b), for example, was discovered independently and almost simultaneously in Cape Town and Rio de Janeiro. Cruls was even awarded the Valz Prize of the Paris Academy of Sciences for his pioneer chemical study of it (Videira 2001).

Secondly, after the coup d'État that set up the Republican regime, in November 1889, the ON became responsible for some decisive tasks in the new State building process, such as the geographical determination of the territory borders and of the area for the new capital, in the Central Plateau (which was built only in the 1950s). It was then, under the direction of Henrique Morize (1908-1930), that the Observatory finally succeeded in moving from its improvised house in the city center to a planned one in the (poor) suburbs, on a small hill still close enough to the port. It was also then that the greatest part of the instruments now deposited in MAST were acquired (Morize 1987).

\section{Conclusion}

The complex ON-MAST was listed by the Brazilian National Institute of Historic and Artistic Heritage in 1986, and by the Rio de Janeiro State Cultural Heritage Institute in 1987, as a result of the same mobilization of intellectual and scientific forces that is in the origin of MAST. The listed heritage comprises the buildings as well the collection of scientific instruments and other significant artifacts derived from the Observatory, including its original furniture.

Since its creation, the multidisciplinary team of MAST, which is formed by historians, 
anthropologists, museologists, archivists and educators, among other specialists, has developed academic research on the ON collections of objects and documents, in order to deepen the understanding of the past astronomical practices in Brazil. These researches are at the basis of the Museum exhibitions. Most importantly, they have supported the successful restoration of many instruments and the astronomical pavilions of the Observatory.

\section{References}

Barboza, C. H. 1994, O encontro do Rei com Vênus; a trajetória do Observatório do Castelo no ocaso do Império (Niterói: Universidade Federal Fluminense, Dissertação de Mestrado (História))

Granato, M. 2009, in: G. Wolfschmidt (ed.), Astronomical Observatories from Classical Astronomy to Modern Astrophysics. Proceedings of the International ICOMOS Symposium in Hamburg, 2008 (Berlin: ICOMOS), p. 122

Morize, H. 1987, Observatório Astronômico; um século de História (1827-1927) (Rio de Janeiro: MAST, Salamandra)

Videira, A. A. 2001, in: A. Heizer \& A.A. Videira (eds.), Civilização e Império nos Trópicos (Rio de Janeiro: Access), p. 123 